\title{
Education towards Sound Moral Values and Religious Values in Kenya: A Philosophical Perspective
}

\author{
Khisa Alfred Simiyu ${ }^{1 *}$, Werunga Khisa Stephen ${ }^{2}$ \\ ${ }^{I}$ Department of Educational Foundations, Masinde Muliro University of Science and Technology P.O Box 190-50100, Kenya \\ ${ }^{2}$ Department of Education Management Kibabii University, P.O Box 1699-50200, Kenya \\ *Corresponding author
}

\begin{abstract}
The greatest challenge in the contemporary world today is living a virtuous life. Aristotle provides an approach of engaging children through habitual training in virtue in an organized educational system. Therefore, Education is crucial in orienting the young towards being responsible citizens to contribute to economic, social and political development of the state. In Kenya, educational system has focused all along in providing Religious Education of the mainstream Religions i.e. Christianity, Islam, Hindu towards attaining sound morals and religious values. However on assessing the products of 8.4.4 and critically examining the situations within the educational set up for instance: Indiscipline, Riots, Drug and substance use, arson, Teacher attacks by student, radicalization etc., there is need to critically question the goal of education in order provide insights that can inform the theory and practice of pedagogical ethic, student-teacher relationship with the aim of attaining holistic education and training for responsible citizenship. Thus, the paper analyzed the national goals of education, traced the philosophical assumptions on human nature towards achieving the goal, analyzed moral education and religious education. It is therefore recommended that education in Kenya should embrace a multidimensional orientation that ensures the moral development, intellectual growth and skill empowerment of learners towards self realization, an informed freedom and self empowerment to act responsibly as valuable citizens.
\end{abstract}

Keywords: Kenya National goals, Reforms, Human nature, sound moral, religious values,

\section{INTRODUCTION}

$\mathrm{E}$ ducation has remained a basic human right for all children in Kenya and according to Wango (2011); education in Kenya has been highly politicized and hence demands continuous reflection and need to realign it with the current constitution. Kenya, like any other state, has set national aims that orient education and training of the young towards being good citizens. Through the education goals, products of an education system can be analyzed, judged and assessed.

According to Nasibi (2003) the use of aims, goals and objectives has been adopted in education planning in order to orient education to the right track and to be in line with international standards. The Ominde commission (1964) had outlined six national goals. However, Kenya Institute of
Education (2009) revised and gave the following goals of education:

i) Foster nationalism, patriotism and promote national unity Kenyans belong to different ethnic groups, races and religions, but these differences need not divide them. They must be able o live and interact as Kenyans. It is a paramount duty of education to help the youth acquire this sense of nationhood, removing conflicts and by promoting positive attitudes of mutual respect, which enable them to live together in harmony, and foster patriotism in order to make a positive contribution to the life of the nation.

ii) To promote the social, economic, technological and industrial needs for national development

Education should prepare the youth of the country to play an effective and productive role in the life of the nation.

\section{$>$ Social Needs}

Education in Kenya must prepare children for the changes in attitude and relationships which are necessary for the smooth process of a rapidly developing modern economy. There is bound to be a silent social revolution following the wake of rapid modernization. Education should assist our youth to adapt to this change.

\section{$>$ Economic needs}

Education in Kenya should produce citizens with skills, knowledge, expertise and personal qualities that are required to support a growing economy. Kenya is building up a modern and independent economy which is in need of adequate domestic manpower.

\section{$>$ Technological and industrial needs}

Education in Kenya should provide the learners with the necessary skills and attitudes for industrial development. Kenya recognizes the rapid industrial and technological changes taking place especially in the developed world. We can only be part of this development if our education system deliberately focused on knowledge, skills and attitudes that will help prepare the youth for these changing global trends. 


\section{iii) To promote individual development and self-fulfilment}

Education should provide opportunities for the fullest development of individual talents and personality. It should help its recipients to develop their potential interests and abilities. A vital aspect of individual development is character building.

\section{iv) To promote sound moral and religious values}

Education should provide for the development of knowledge, skills and attitudes that will enhance acquisition of sound moral values and help children to grow up into self-disciplined, self-reliant and integrated citizens.

\section{v) To promote social equality and responsibility}

Education should promote social equality and foster a sense of social responsibility within an education system which provides equal education opportunities for all. It should give all learners varied and challenging opportunities for collective activities and corporate social services irrespective of gender, ability or geographical environment.

vi) To promote respect for and development of Kenya's rich and varied cultures

Education should instill in the youth of Kenya an understanding of past and present cultures and their valid place in the contemporary society. The children should be able to blend the best of traditional values with the changed requirements that must follow rapid development in order to build a stable and modern society.

vii) To promote international consciousness and foster positive attitudes towards other nations

Kenya is part of the international community. It is part of the complicated and interdependent network of people and nations. Education should, therefore, lead the youth of the country to accept membership in this international community with all the obligations and responsibilities, rights and benefits that this membership entails.

viii) To promote positive attitudes towards good health and environmental protection

Education should inculcate in the youth the value for good health in order to avoid indulging in activities that will lead to physical or mental ill health. It should foster positive attitudes towards environmental development and conservation. It should lead the youth to appreciate the need for a healthy environment.

\section{EDUCATION REFORMS AND ACHIEVEMENT OF NATIONAL GOALS}

Since the formulation of the goals by the Ominde commission (1964), the main focus at the time was to realign education policies to address existing racial and human capital problems. Thus, the main focus was placed on national unity which was already lacking because of colonialism. The domineering theoretical framework guiding this process included human capital theory and conservation theory. The Harambee spirit to alleviate poverty, hunger and illiteracy was embraced with a social approach and nationalistic slogan "Harambee". (Wanyama P.M., 2013)

The need for evaluating the financing policy of education in Kenya brought on board the Gachathi commission (1976) with a proposal to change the system of education to 9-2-4, thus laying emphasis on early childhood development and need for cost sharing. From a pragmatic perspective education was to be realized at minimal cost by the government at all cost. This was to favour the political class in power at that time (Cheserek G.J and Mugalavai, 2012).

Since university education was becoming a demand for the young Kenya, in order to prevent brain drain to Europe, The Mackay Commission (1981) was set up and proposed the setting up of Moi University as the second university in Kenya, scrapping off all A-level segments and introducing the 8.4.4 system of education. This commission, from a human capital, pragmatic and conservationist perspective, provided a new system. However, critics have had reservation on how the government introduced and implemented the 8.4.4 curriculum (Wanyama P.M., 2013)

With the overemphasis placed on acquisition of skills for the future generations, the need for technical education and training was proposed by the Kamunge Commission (1988).The incorporation of technical subjects in the curriculum provided room for students to engage hands, minds and hearts in the learning process. A strong professional structure was to be laid in order to provide a skilled labour force for the country's development agenda (Nasongo,J., \& Musungu,L., 2009).Using the pragmatic approach learners involved in technical subjects got skills for self employability as masons, carpenters, and electricians at both post primary and post secondary levels. However, later in 2007, the government scrapped off the technical subjects in primary education level, citing increased workload for the primary school children.

Still in evaluating whether the system was attaining national unity towards the millennium, the Koech Commission(1999) was set up to assess education and in its findings, recommended that focus should be placed national unity and mitigating financial constraints in the government spending. Using conservative and pragmatic approaches free basic education was to be expanded. Finally the Koech Commission (2011) analyzed the implication of the Kenya's 2010 constitution to education and assessed educational gaps in curriculum delivery. From a perrenalistic and pragmatic approach, focus was now placed on policy orientation and progressive assessment framework. This alignment was to conform with the laws of the state in order to ensure full control on education (Cheserek G.J and Mugalavai, 2012).

Guided by international standards, Kenya has always realigned education and training to be in line with 
international demands that champion education for all and education as a right to the young. The right to education in Kenya is provided for under the Constitution. Key international instruments defining the right to education include: The Universal Declaration of Human Rights, The International Covenant on Economic, Social and Cultural Rights, The United Nations Convention on the Rights of the Child (CRC), UNESCO Convention Against Discrimination in Education, The Convention on the Elimination of All Forms of Discrimination against Women (CEDAW), The Millennium Development Goals (MDGs), The African Charter on Human and Peoples Rights, The African Charter on the Rights and Welfare of the Child (Wango, 2011).

From the above analysis, it is very clear that the overemphasis laid on national unity had some political connotations and the government of the time used the commission to affirm its objectives and influence in education. In addition, moral values and religious values were either implicitly achieved or not achieved at all since knowledge, skills and national values took centre stage of the commissions' deliberations. The commissions also did not highlight on pedagogical ethics and how teachers and children where to interact at school.

\section{Human nature and Search for the Absolute}

Philosophy as the study of reality as it is since ancient civilizations man has remained at the centre of this enterprise. The study of the cosmos, man and the spirit has remained objects of reflection in the entire discipline of philosophy (Kiruki, 2004). According to Plato and Aristotle man was composed of the body and soul. The corporeal being of man was mortal whereas the soul was immortal. In the hierarchy of all beings man thus occupied the first level because of his rational mind that is superior to all beings (Kiruki, 2004).

In the light of Aristoteliansm, St Thomas Aquinas introduced the aspect of participation. Man with his rational mind was able to discover and know the unknown from perception, sense experience and contemplation (Kiruki, 2004).Through the natural law and the divine dictates, man can be catechized to learn and search for the "good" (Ada.M.J., 2012). Still in the spirit of eudaemonological and teleological standpoint in the theory of the conduct of man, opines that only free acts are moral because they are done willingly (Kiruki, 2004). The concept of responsibility and freedom come in and thus reinforces the notion of character formation and development for one to attain that sound mind to execute actions with reason beyond any doubt. Thus man is subject to the church and other authorities when it comes to values and his conduct.

The Renaissance on the other hand brought back mans image and discovery of inner potential by recanting the total submission to divine will and church authorities that lacked reasoning.Blaise Pascal (1463-1662) opines that man is but a reed, the weakest of nature but a cute reed and on the other hand Rene Descartes in his maxim "cogito ergo sum" places mans rationality at the centre of his being in the cosmos (Bugiulescu, 2018). This age intellectually desacralised and dehumanized man and placed him forth in the universe to contemplate the self as postulated by Socrates "Know thyself".

The social contract theorists also opine that man by nature is social being. Hobbessian state of nature formulated on the concept of war against all, man by nature is in continuous search for the self and self preservation. On the other hand, John Loke sees man as born Tabula rasa, all what he is is only through experiences (Bugiulescu, 2018). The aspects outstanding in these theorists are continuous self preservation and experiential learning. Virtues therefore, can be accrued through the educational experiences and crisis like war and strikes.

Existentialist have always viewed man as a being with inner potential of converting crisis to fruitful opportunity for life. In the Dasein concept, Martin Heidegger introduces man born as "tossed" into the world to death. Thus man had no choice to be born (a mere possibility), man as a beast(only thrown in the universe) and finally man as one who can fall (the fact to be fell).The concept of the absolute is introduced in order to offer hope the condemned man to resituate his destiny (Bugiulescu, 2018).

\section{RELIGION AND EDUCATION IN KENYA}

According to Joachim Wach religion is a belief system, a ritual worship system and a moral system of social relationships. Man $a b$ initio has been thought to be religious (Mbithi, 1988). Etymologically, Cicero deduces the world religion from Latin word relegere (to recite, to meditate or to reflect), Virgiliu get it from Latin word relinquere( to remain, to distinguish, to put aside) whereas philologists and theologians deduce it from Latin word religare ( to link or mutually winding).Religion therefore is a conscious act of man with clear intentions of uniting, knowing him and realities of life (Bugiulescu, 2018).

There has been a mutual relationship between faith based institutions and the state on matters of development and education. Majority of the schools were established and ran by first missionaries in Kenya and later handed over to the government (Sifuna,D.,\& Otiende,E., 2009). The religious leaders only participate in pastoral programmes and Religious education instructions towards orienting the young towards knowing the deity.

\section{Achievement of sound moral values and religious values in} Kenya

The moral concept is broad. From a philosophical point of view, the adjective "sound" hints to us the existence of some morals that are unsound. The dualistic expo of the value system in education presupposes the notion of "right" and "wrong". Etymologically the word morals come from a Greek word "mores" meaning "character or conduct". Morality has been viewed as a philosophical concept that has rules which regulate our social interactions with one another in in order to 
achieve social welfare, justice, responsibility and human rights (Kaur, 2015).

\section{Agents of moral education and training}

It is through moral education that vital common beliefs that shape our relations to each other are attained. Moral values may include; integrity, honesty, responsibility etc. These values can not only be centralized in a school set up but can also be promoted by other agents. They can be acquired from school, parents, society, teachers and religious institutions (Kaur, 2015). According to Kaur (2015), schools provide an environment with viable programmes for critical reasoning and helping students to critically examine contradicting cases and seek clarity. The precense of school rules and other teaching staffs provide a relational environment that provides support and reinforcement of positive values. Peers or other age mates that the learner meets in the social set ups greatly influence his or her character

The overemphasis on the teacher as the sole provider of the moral development plan to the learner has been the perception of all stakeholders. There exist dilemmas in the teaching environment that require the input of guardians and even the government. Teachers in the school are immediate role models, the mediators between the curriculum and learners and providers of answers to existing moral contradictions (Chowdhury, 2016 ).The provision of education requires consistency and informed teachers who are grounded in pedagogical ethics. (Kaur, 2015)

Parents also play a crucial role in placing their children in specific environments to acquire specific values. In addition they are first educators and trainers of the children in values. They also provide affective relationship and extensive interactions that facilitate growth in the desired values.

Religious institutions based on the theological doctrines have developed values that are handed over to the young through formal and informal training. For Islam, Madrasa must be attended by all the young; for Catholics catechetical lessons must be attended by all faithful before being enrolled in a sacramental life of the church. According to Kaur (2015), though each religion has its doctrine, there is a great overlap in the moral values. The overlap in religions may be based on the understanding of the individual, society and social morality and some time can be sources of conflict. (Chowdhury, 2016 )

\section{Efforts towards achieving sound morals and religious values}

Through the curriculum developers, The Kenya Institute of Education did avail the syllabuses for Social Ethics Studies, Christian Religious Education (CRE), Islam Religious Education (IRE), and Hindu Religious Education (HRE) for basic education in Kenya to offer skills, knowledge and attitudes vital in provoking critical thinking and resolving moral dilemmas.

The introduction of Guidance and counseling services to learners and pastoral guidance by religious leaders has always availed religious values, provided shift from vices and encouraged positive attitudes in the lives of learners.

The government through its organs has eliminated radicalized groups that could propagate vices in the society and this has encouraged many youths to observe the law at all times.

Challenges towards realizing moral soundness and religious values in Kenya

First and foremost, the changed parental lifestyles; modernization and change in family set up has encouraged single parenting, on job parents who leave their children under the maids watch. From the premise that the family is the first school, where parents are teachers, the children in this case will emulate and learn from maids since parents are absent. Parenting styles have also enhanced protectionism, an element that protects children from being corrected by any external individual. This has bred youths with excess freedoms without responsibility and that is why picketing, strikes and arsons are chosen as avenues for expressing anger.

Secondly, an exam oriented system has motivated stakeholders to redirect their energies to learner's performances rather than the body of knowledge, attitude and skills acquired. The overemphasis on exams limits the agents of moral education in providing praxis oriented learning and thus the system is void of practical wisdom and responsibility.

Thirdly, secularization has cropped into the society and as a result groups with extreme ideas oppose existing institutions and existing societal norms. Radicalization crops into the society and youth hitting back to the agents of moral education e.g. churches, mosques, schools in order to eliminate them. Radicalized Alshaabab remains a great challenge for us today.

Fourthly, technological empowerment of the youth has exposed many youths to porn materials, cyber crimes, bullying, a vice system that promotes the "other" rough and strong deviant group. These vices are usually exposed to learners through media and phones can be hazardous in bringing up the young who can access the vice sites.

\section{PROPOSED RE INTERVENTIONS TOWARDS ACHIEVING SOUND MORALS AND RELIGIOUS VALUES IN KENYA}

a. The education reforms in line with attaining educational goals to involve all stakeholders in order to share the burden of moral education and character formation and try to remove the perceptions that moral training in Kenya's education is the sole role of teachers.

b. With the ongoing rate of secularization and radicalization, the government to regulate faith based organizations formations, their content (doctrines) and formation of militia groups that might enroll the young into wild doctrines.

c. Teacher training to be enriched by pedagogical ethics that shall orient teacher trainees to facilitate smooth 
interactions among learners and other members of the society for peaceful coexistence

d. Civic education to be done before electioneering year in order to facilitate choice of sound morally upright leaders to be role models for the young generation. Lack of civic education on the vitality of choosing leaders with integrity has reduced elections to tribal and ethnical sharing of power.

e. To kill the corruption syndrome in Kenya, there is need for a collective agreement by the entire nation to invest in an education system that upholds knowledge, skills and attitudes rather than grades and this can only be achieved through revision of goals and education in the light of existing Kenyan situations.

f. Student council leaders to be oriented on freedom and responsibility and their roles in forming the future society.

g. Parents and other stakeholders to redirect their energies in modeling the young rather than over protectionism and excesses in education training and character formation.

\section{CONCLUSION}

This paper has interrogated the goals of education in Kenya and attempted to trace the efforts in education reforms using a historical perspective to identify input of the commissions in addressing the goal on moral and religious values. The findings indicated that little effort was placed on attaining moral values National unity, cost sharing in education, skill empowerment among other occupied the commissions' recommendations, in addition, the overemphasis of teacher's role in moral education must be addressed by treating moral training as a collective responsibility of all education stakeholders. The findings of such research undertaking will unearth any underlying currents that need to be addressed, and provide baseline information for education policy makers and implementers.

\section{REFERENCES}

[1] Ada.M.J., A. \&. ( 2012). Saint Thomas Aquinas Theories on Man, Society, Government, law and Applicabilityof these ideas in the Administration of Nigerian Secondary Schools. World J Young Researchers, Issue 2 vol (5) pp 65-69.

[2] Andafu, E., \& Simatwa, E. (2014). A Crituque of the Kenyan system of education in view of the Freirian Concept of education:A philosophical perspective. International Research Journals, 5(8), 331-347.

[3] Aquinas, T. (1947). Summa Theologica Benziger Bros. edition. Ohio: Translated by Fathers of the English Dominican Province (Original work completed 1259-1264).

[4] Bugiulescu, M. (2018). Man as a Religious, Rational,Free and Conscious Being. International Journal of Theology, Philosophy and Science, No. 2, Year 2 pp 5-16.

[5] Cheserek G.J and Mugalavai, V. (2012). Challenges and Reforms Facing Kenyan Education System in the 21st Century : Intergrating the Principles of Vision 2030 and constitution 2010. Journal of Emerging Trends in Educational Research and Policy Studies, 471-478 Vol .3 No.4.

[6] Chowdhury, M. (2016 ). Emphasizing Morals, Values, Ethics, And Character Education In Science Education And Science Teaching.
The Malaysian Online Journal of Educational Science, Volume4 Issue 2 pp 1-16.

[7] Fatih, M. (2018). Values Education or Religious Education? An Alternative View of Religious Education in theSecular Age, the Case of Turkey. Education Science, pp 1-16.

[8] Griffiths, M. ( 2014). Re-thinking the relevance of philosophy of education for educational policy making. Educational Philosophy and Theory, 46 (5) pp 1-21.

[9] Gülcan, N. (2015). Discussing the importance of teaching ethics in education. Procedia - Social and Behavioral Sciences, 2622 2625.

[10] Jarosław, H. (2020). Christian religious education and the development of moral virtues: a neo-Thomistic approach. British Journal of Religious Education, 42:4, 447-458.

[11] Kaur, S. (2015). Moral Values In Education. Journal Of Humanities And Social Science, Volume 20, Issue 3, PP 21-26.

[12] KAYMAKCAN.R., \&. M. (2012). Values in the Curricula of Religious Education and Social Studies in Primary Schools in the Context ofLocal-Universal Dilemma*. Educational Sciences: Theory \& Practice, 12 (2) Supplementary Special Issue PP 15881591.

[13] Kenya Institute of Education (KIE) . (2013). Craft Certificate in Building Technology Syllabus and regulations. Nairobi: Kenya Institute of Curriculum Development.

[14] Kiruki, J. K. (2004). Introduction to Critical Thinking. Eldoret: Zapf Chancery Research Consultants and Publishers.

[15] Mbithi, J. (1988). African Religions and Philosophy. Nairobi: Heinemann.

[16] Nasibi W.M., N. (2003). Instructional Methods: Teaching Across the Curriculum. . Nairobi : Strongwall Africa.

[17] Nasongo,J., \& Musungu,L. (2009). The Implications of Nyerere's theory of education to contemporary education in kenya. Educational Research and Reviews, 4(4), 111-116.

[18] Niculescu R. M., \&. N. (2013). Religious education an important dimension of human's education. P r o c e d i a - S o c i a l a n d B e h a viora $1 \mathrm{Sc}$ ie n c e s, PP 338-342.

[19] Njoroge,R.,\& Bennaars, G. (1990). Philosophy of Education . Nairobi: Transafrica Press.

[20] Nyasani, J. (2010). Philosophy of Development,An African Perspective:Reflections on why Africa may never develop on the Western Model. Nairobi: Consolata Institute of Philosophy.

[21] Republic of Kenya, (. ( 1981). Second University in Kenya (Mackay Report). Nairobi: Government Printer.

[22] Republic of Kenya, (. (1964). Kenya Education Commission,. Nairobi: Government Printer.

[23] Republic of Kenya, (. (1976). Report of the National Committee on Educational Objectives and Policies (Gachathi Report) . Nairobi: Government Printer.

[24] Republic of Kenya, (. (1988). Report of the Presidential Working Party on Education and Manpower Training for the Next Decade and Beyond, (Kamunge Report). Nairobi: Government Printer.

[25] Republic of Kenya, (. (1999). Report of the Inquiry into the Education System of Kenya (TI QET) Koech Report. Nairobi: Government Printer.

[26] Sifuna,D.,\& Otiende,E. (2009). An Introductory History of Education. Nairobi: University of Nairobi Press.

[27] Thenjiwe,M.,\& Thalia,M. (2009). Julius Nyerere(1922-1999), an African Philosopher, Reenvisions Teacher Education to Escape Colonialism: XZ. Journal of Marxism and Interdisplinary Inquiry, $3(1), 15-22$.

[28] Wango, G. M. (2011). Kenya New Constitution and Education: Education in Kenya Under the New Constitution. Nairobi: Task Force on the Realignment of the Education System to the Constitution of Kenya.

[29] Wanyama P.M., \&. C. (2013). Education Reforms in Kenya for Innovation. International Journal of Humanities and Social Science, Vol. 3 No. 9 pp 124- 145. 